\title{
TILLANDSIA SUESILLIAE ESPEJO, LÓPEZ-FERRARI ET W. TILL, A NEW SPECIES FROM CENTRAL MEXICO
}

\section{Adolfo Espejo Serna ${ }^{1}$, Ana Rosa López-Ferrari ${ }^{1}$ and Walter TilL ${ }^{2}$}

${ }^{1}$ Universidad Autónoma Metropolitana-lztapalapa, División de Ciencias Biológicas y de la Salud, Departamento de Biología, Herbario Metropolitano, 09340 México, D.F. aes@xanum.uam.mx

${ }^{2}$ Institut für Botanik der Universität Wien, Rennweg 14, A-1030, Wien, Austria

\section{ABSTRACT}

The nomenclatural statuses of Tillandsia parryi Baker and T. sueae Ehlers are clarified, and T. suesilliae is described as new. Data relative to the distribution, ecology and phenology of the studied taxa are provided.

Key words: Bromeliaceae, Hidalgo, Mexico, San Luis Potosí, Tillandsia parryi, Tillandsia sueae.

\section{RESUMEN}

Se aclara la aplicación correcta de los nombres Tillandsia parryi Baker y T. sueae Ehlers y se describe como nueva T. suesilliae. Se aportan datos relativos a la distribución, ecología y fenología de los taxa estudiados.

Palabras clave: Bromeliaceae, Hidalgo, México, San Luis Potosí, Tillandsia parryi, Tillandsia sueae.

Tillandsia parryi was described by Baker in 1887, based on material collected by C. Parry and E. Palmer (\# 873) in the state of San Luis Potosí, Mexico. The labels of those specimens do not provide data about the precise locality where the plant was found; not even McVaugh (1956), in his contribution about the travels of Parry and Palmer, provides information to determine the exact place where the above mentioned plants came from, although doubtless it is a place near Sierra de Álvarez, in the region east of the city of San Luis Potosí. 
Gardner, in her doctoral thesis (1982), pointed out that in San Luis Potosí it is possible to find at least two distinct forms "two types" of plants named Tillandsia parryi, one with violet petals and another with green petals. She concluded that ".... these types are distinct enough to be recognized as distinct species. The latter [that of green petals] is interpreted as T. parryi, but dried specimens are difficult to determine." However, she did not provide evidence to support her assertion, and did not mention if she had seen type material.

Ehlers (1991), without providing more data, assumed as true Gardner's interpretation (1982) and described the taxon with violet flowers as Tillandsia sueae. However, a careful microscopic revision of the flowers of the type material of Tillandsia parryi (Parry \& Palmer 873 (GH!, K!, MO!, PH!, US!)) showed that the petals of this taxon are violet and not green as was supposed by Gardner. For the reasons previously stated, we conclude that Tillandsia sueae Ehlers is a taxonomic synonym of $T$. parryi Baker, while the species with green petals has no name, so we propose:

Tillandsia suesilliae Espejo, López-Ferrari et W. Till, sp. nov. Figs. 1 and 2.

Herba lithophytica, acaulis, rosulata, florens usque ad $80 \mathrm{~cm}$ alta; folia numerosa, vaginae distinctae, triangulares, $10.5-13 \mathrm{~cm}$ longae, 4-6.5 cm latae; laminae triangulares 30-50 cm longae, 3.5-4.2 cm latae; pedunculus erectus, teres, $18-40 \mathrm{~cm}$ longus; inflorescentia unico-ramulosa; spicae ellipticae usque ad oblongo-ellipticae, 9.5-18 cm longae, 1.7-2.3 cm latae; bracteae florales virides, rarius roseae, imbricatae, oblongo-ellipticae, 3.9-5 cm longae, 1.3-1.8 cm latae, praeter apicem ecarinatae, dense albo-lepidotae; flores distichi, corolla actinomorpha, tubiformis; petala viridia, spathulata, 5.2-6.1 cm longa, 8.8-10 mm lata; stamina et stylus exserta.

Saxicolous, stemless herbs, flowering $60-80 \mathrm{~cm}$ tall, with funnelform tank type rosettes $30-50 \mathrm{~cm}$ in diameter, solitary. Leaves numerous, sheaths distinct, tinged with purple, especially on the adaxial surface, oblong-elliptic, $10.5-13 \mathrm{~cm}$ long, 4-6.5 cm wide, densely lepidote on both surfaces, blades green-greyish, narrowly triangular to linear-triangular, curved, involute at the margins, densely whitelepidote on both surfaces, 30-50 cm long, 3.5-4.2 cm wide, apex long-attenuate, acute. Inflorescence terminal, erect, compound, once branched, with 12 to 15 adpressed to ascendent spikes, peduncle terete, $18-40 \mathrm{~cm}$ long, 5-7 $\mathrm{mm}$ in diameter, covered by the bract sheaths; peduncle bracts green-greyish, foliaceous, narrowly triangular, $14-23 \mathrm{~cm}$ long, reducing their size gradually towards the distal portion of 
Espejo et al.: Tillandsia suesilliae, a new species from Central Mexico

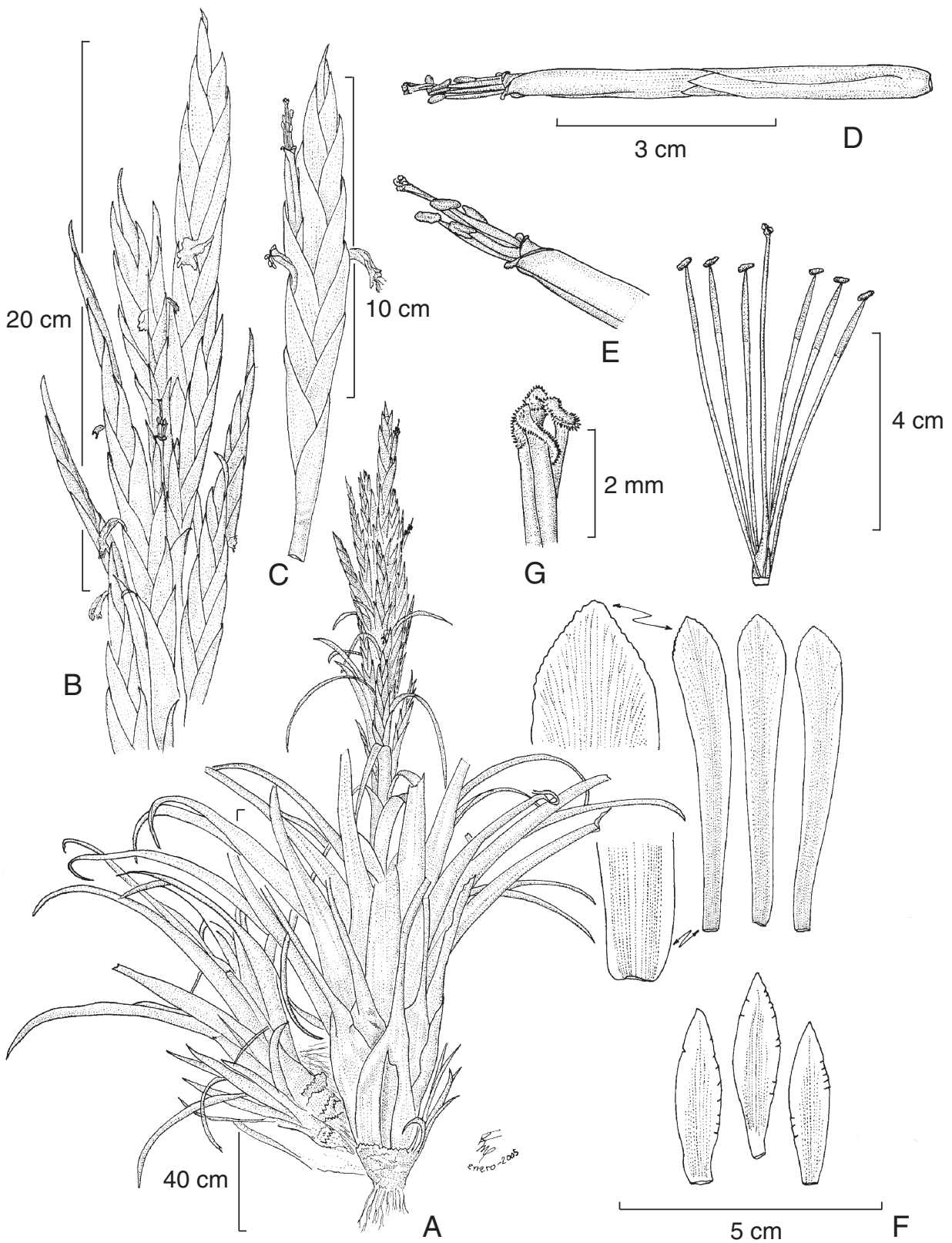

Fig. 1. Tillandsia suesilliae Espejo, López-Ferrari \& W. Till. A. habit; B. inflorescence detail; C. spike; D. flower; E. flower detail; F. flower dissected; G. stigma. Voucher: J. Ceja et al. 1745. 


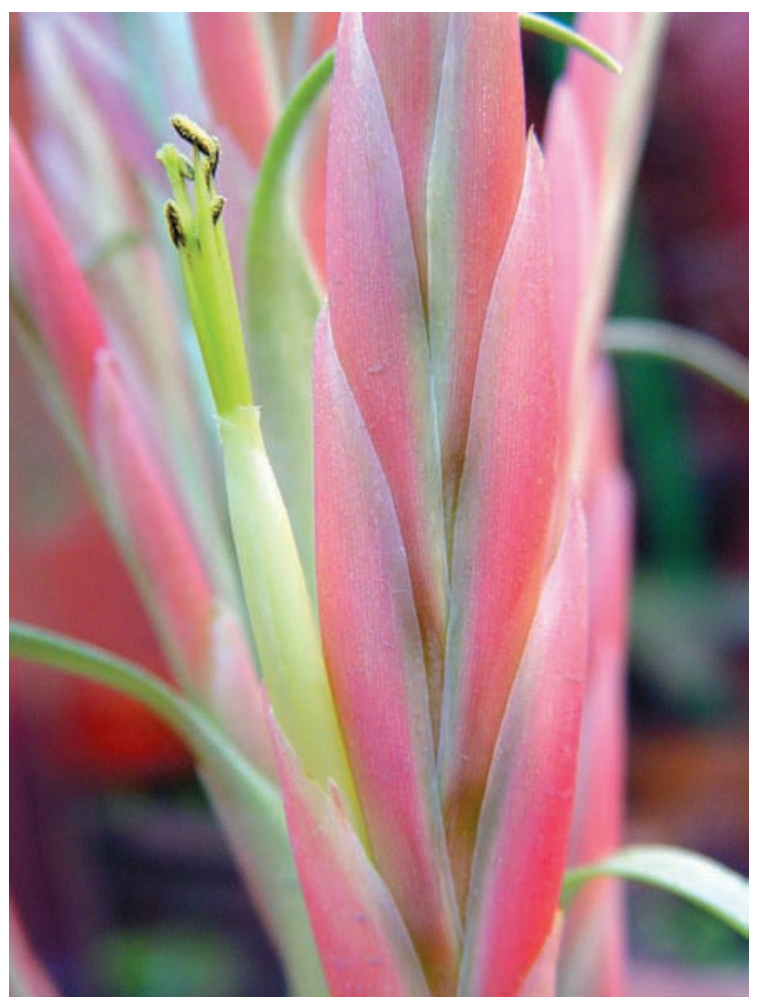

Fig. 2. Tillandsia suesilliae Espejo, López-Ferrari \& W. Till. Inflorescence detail. Voucher: J. Ceja et al. 1745.

the peduncle; spikes compressed, narrowly elliptic, 9.5-18 cm long, 1.7-2.3 cm wide, stipes 1.2-1.5 cm long, slightly compressed; primary bracts green-greyish, 6-14 cm long, those of the distal portion vaginiform; floral bracts green to rose colored, longer than the internodes, imbricate but the rachis visible after anthesis, elliptic, 3.9-5 cm long, 1.3-1.8 cm wide, ecarinate except at the apex, densely white-lepidote, acuminate; flowers distichous, adpressed, 6-10(-11) per spike, subsessile, corolla actinomorphic, tubiform; sepals green, free, narrowly elliptic, 3.4-3.5 cm long, 9-10 mm wide, nerved, the two adaxial carinate, glabrous; petals free, green in the apical half, white toward the base, spathulate to oblong-spathulate, 5.2-6.1 cm long, 8.8-10 mm wide, obtuse; stamens longer than the petals, in two series of unequal length, filaments green in the apical half, white toward the base, flat (ribbon-like) in the basal part and somewhat thickened distally although also somewhat compressed, 5.8-6.6 $\mathrm{cm}$ long, anthers black, oblong, 3.7-4 mm long, dorsifixed; ovary ellipsoid, 7.5-9 mm 
long, ca. $3 \mathrm{~mm}$ in diameter, style exceeding the petals, filiform, $6.3-6.5 \mathrm{~cm}$ long, stigma green, conduplicate-spiral. Capsule fusiform, shortly mucronate, 3-3.3 cm long, 5-6.5 mm in diameter; seeds reddish-brown, fusiform, ca. $3 \mathrm{~mm}$ long, with a white coma $1.8-2 \mathrm{~cm}$ long.

Type: San Luis Potosí, municipio de Zaragoza, 1.5 km después de Las Rusias, rumbo al Valle de los Fantasmas, 2203'12" N, 100³4'01" W, 1964 m s.n.m., saxícola, 12.IX.2005, J. Ceja, A. Espejo, A. R. López-Ferrari, A. Mendoza R. \& I. Ramírez M. 1745 (holotype UAMIZ; isotypes: IEB, MEXU, WU).

Paratypes: Hidalgo: municipio indefinite, on canyon walls on road from Jacala to Tamazunchale, J. Anderson s. n. (SEL); San Luis Potosí: municipio de Zaragoza, in Valley of the Phantoms, about $40 \mathrm{~km}$ east of San Luis Potosí, saxicolous, C. S. Gardner 306 (US); municipio de Zaragoza, Valle de los Fantasmas, saxícola, C. S. Gardner 807 (SEL, US); municipio de Zaragoza, Sierra de Álvarez, 22-25 (37.4-42.5 $\mathrm{km}$ ) road miles east-southeast of San Luis Potosí, R. McVaugh 12282 (MICH(x2)).

Other records: Line drawing in Gardner's thesis (1982, p. 150) and in Sill (2002, p. 209 and 212).

Tillandsia suesilliae is known only from the states of San Luis Potosí and Hidalgo, Mexico (Fig. 3), growing as a saxicole on calcareous cliffs surrounded by Quercus forests, between 1800 and $2350 \mathrm{~m}$.

The new species shares some similarities with Tillandsia parryi but is easily distinguished by the characters shown in table 1 .

Tillandsia parryi Baker, J. Bot. 25: 277. 1887. Type: San Luis Potosí, chiefly in the region of San Luis Potosí, $22^{\circ}$ N, C. C. Parry \& E. Palmer 873 (holotype: K!; isotypes: GH!, MO!, PH!, US!). Fig. 4.

Tillandsia sueae Ehlers, J. Bromeliad Soc. 41: 208-213, fig. 6, 9-11. 1991, syn. nov. Type: Tlaxcala "Puebla", circa urbem Tlaxcala, III-1982, R. \& K. Ehlers EM 82134 (holotype: WU 3760!; isotypes: WU 3761!, 3762!).

Saxicolous or epiphytic, stemless herb, flowering 60-80 cm tall, with funnelform, tank type rosettes to $65 \mathrm{~cm}$ in diameter, solitary or forming groups of two or 


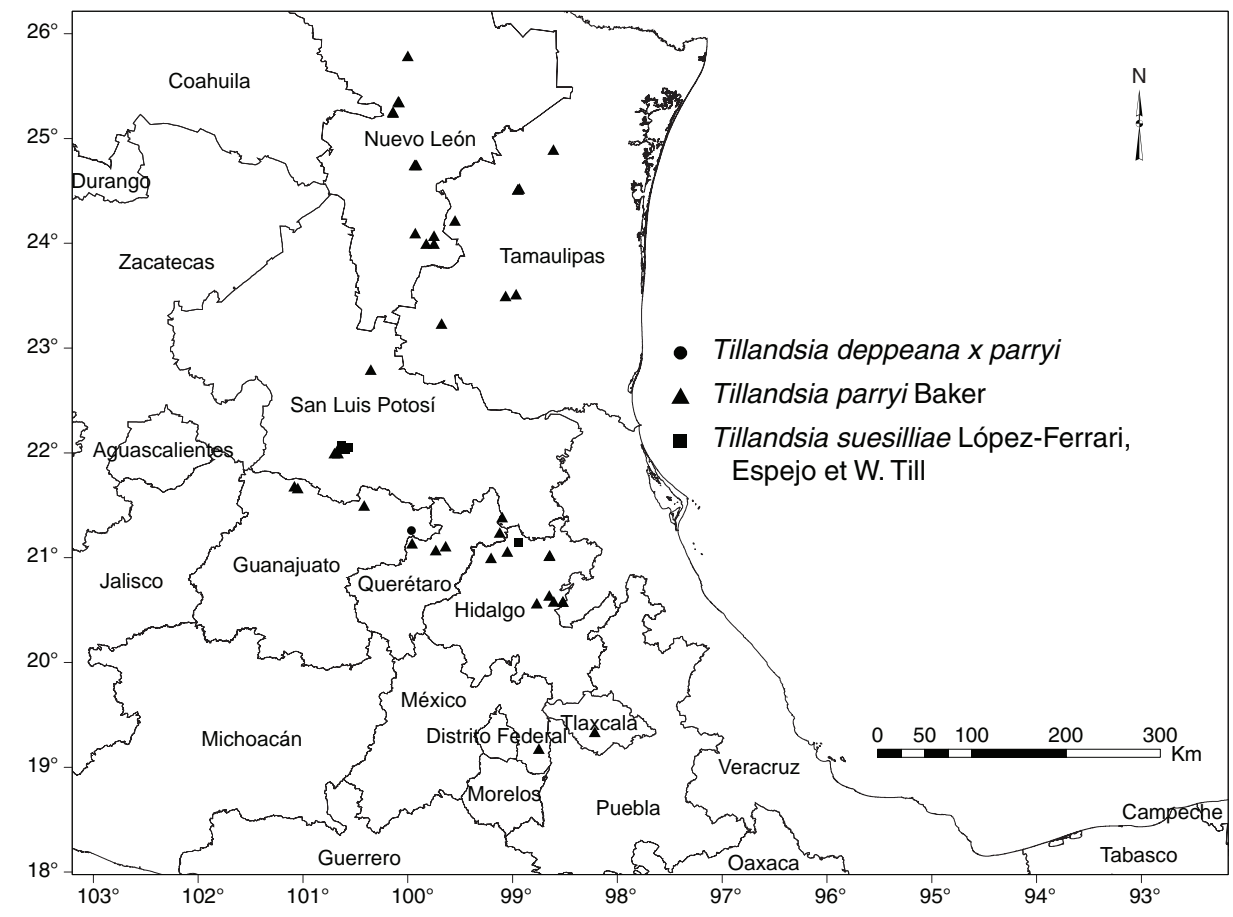

Fig. 3. Distributions of Tillandsia deppeana x parryi, T. parryi and T. suesilliae.

three rosettes. Leaves numerous, sheaths distinct, pale brown abaxially, dark brown on the adaxial surface, oblong-elliptic, 10-18 cm long, 5.5-10 cm wide, densely lepidote on both surfaces, blades green-greyish, narrowly triangular to linear-triangular, curved, involute at the margins, densely white-lepidote on both surfaces, 44-70 cm long, 3.5-3.7 cm wide, apex long-attenuate, acute. Inflorescence terminal, erect, compound, once-branched or occasionally twice-branched at the base, with 12 to 22(-30) adpressed to ascending spikes, peduncle terete, 24-35 cm long, ca. $7 \mathrm{~mm}$ in diameter, covered by the bract sheaths; peduncle bracts green-greyish, foliaceous, narrowly triangular, 29-40 cm long, the apex long-attenuate, reducing their size gradually towards the distal portion of the peduncle; spikes compressed, narrowly elliptic, 9-24 cm long, 1.5-2.7 cm wide, stipes 1.5-1.7 cm long, slightly compressed; primary bracts green-greyish, (5.5-)6.5-31 cm long, those of the distal portion vaginiform; floral bracts red to orange colored, longer than the internodes, imbricate but with the rachis visible after anthesis, elliptic, 2.7-3.6 cm long, 1.2-1.6 cm wide, ecarinate except at the apex, densely to sparsely white-lepidote, glabrescent with 
Table 1. Comparative characters of T. parryi Baker and T. suesilliae Espejo, López-Ferrari et W. Till.

\begin{tabular}{|l|l|l|}
\hline & Tillandsia parryi & Tillandsia suesilliae \\
\hline Habit & epiphytic or saxicolous & saxicolous \\
\hline Inflorescence & $\begin{array}{l}\text { once branched to twice } \\
\text { branched }\end{array}$ & once branched \\
\hline Scape bracts & $29-40 \mathrm{~cm}$ long & $14-23 \mathrm{~cm}$ long \\
\hline Floral bracts & $\begin{array}{l}2.7-3.6 \mathrm{~cm} \text { long, red to orange } \\
\text { colored }\end{array}$ & $\begin{array}{l}\text { 3.9-5 cm long, green to rose } \\
\text { colored }\end{array}$ \\
\hline Sepals & $2.3-3 \mathrm{~cm}$ long & $3.4-3.5 \mathrm{~cm}$ long \\
\hline Petals & $4.6-5.2 \mathrm{~cm}$ long, violet & $5.2-6.1 \mathrm{~cm}$ long, green \\
\hline Stamens & $5-5.8 \mathrm{~cm}$ long, violet & $5.8-6.6 \mathrm{~cm}$ long, green \\
\hline Anthers & $3-3.5 \mathrm{~mm}$ long & $3.7-4 \mathrm{~mm}$ long \\
\hline Capsule & $4.6-5 \mathrm{~cm}$ long & $3-3.3 \mathrm{~cm}$ long \\
\hline Seeds & $3.5-4 \mathrm{~mm}$ long, dark brown & $3 \mathrm{~mm}$ long, reddish-brown \\
\hline
\end{tabular}

age, acuminate; flowers distichous, adpressed, (6-)9-11 per spike, subsessile, corolla actinomorphic, tubiform; sepals green, free, elliptic, 2.3-3 cm long, 7.5-10 mm wide, nerved, the two adaxial ones carinate, glabrous, acuminate; petals free, violet in the apical half, white toward the base, oblong to oblong-spathulate, 4.6-5.2 cm long, 6.5$7 \mathrm{~mm}$ wide, acute, stamens longer than the petals, in two series of unequal length, filaments violet in the apical half, white toward the base, flat (ribbon-like) in the basal part and somewhat thickened distally although also somewhat compressed, 5$5.8 \mathrm{~cm}$ long, anthers black, oblong, 3-3.5 mm long, dorsifixed; ovary ellipsoid, 7-10 $\mathrm{mm}$ long, $1.5-2 \mathrm{~mm}$ diameter, style exceeding the petals, violet in the apical half, white toward the base, filiform, 5.5-6 cm long, stigma violet, conduplicate-spiral, papillate. Capsule green to brownish, fusiform, rostrate, 4.6-5 cm long, 5-7 $\mathrm{mm}$ in diameter; seeds dark-brown, fusiform, 3.5-4 mm long, with a white coma ca. $1.8 \mathrm{~cm}$ long.

Examined specimens: Guanajuato: Guanajuato, A. Dugès s. n. (GH); municipio de Jaral del Progreso, Jaral, W. Schumann 1514 (P, US, WU); municipio de San 


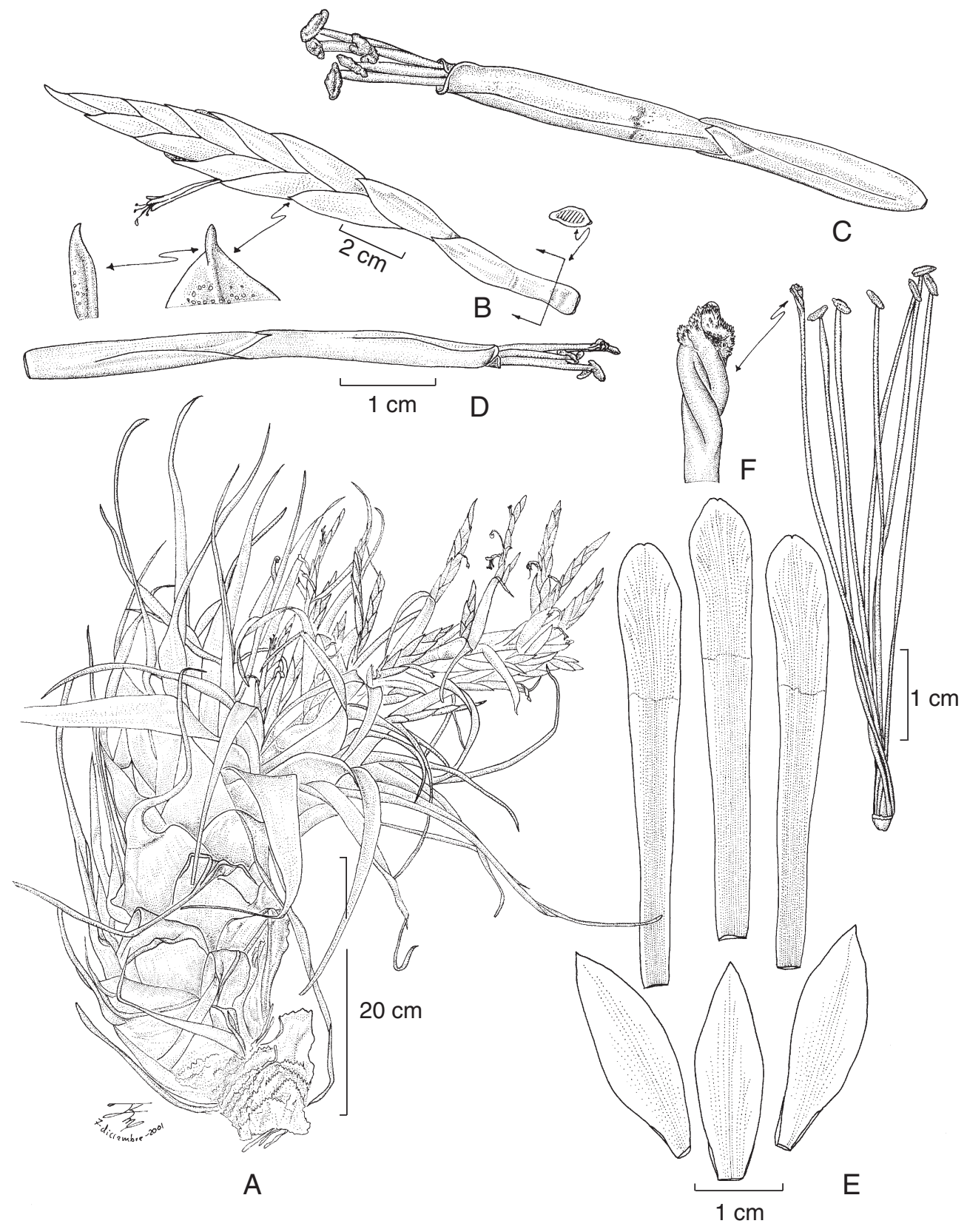

Fig. 4. Tillandsia parryi Baker. A. habit; B. spike; C, D. flower; E. flower dissected; F. stigma. 
Luis de la Paz, cerro El Chapín, por Mesas de Jesús, E. Ventura V. \& E. López 9837 (IEB(x2), UAMIZ(x2)). Hidalgo: municipio de Jacala, cerca de Jacala, E. Matuda 38659 (MEXU(x4)); municipio de Zimapán, 28.1 miles S of Huejutla along hwy to Pachuca, J. Utley \& K. Burt-Utley 7325 (MEXU); municipio de La Misión, 20 miles N of Jacala, O. van Hyning 594 (US(x2)); municipio de Metztitlán, Meztitlán, $R$. Ehlers 942403 (M(x2)); municipio de San Agustín Mezquititlán, ca. 4 km después de Carpinteros, rumbo a Huayacocotla, J. Ceja, A. Espejo \& A. R. López-Ferrari 1298 (UAMIZ(x3)); municipio de San Agustín Mezquititlán, ca. 6 km después de Carpinteros, rumbo a Huayacocotla, ca. 600 m después del ejido forestal La Selva, $J$. Ceja, A. Espejo \& A. R. López-Ferrari 1300 (CICY(x2), UAMIZ(x2)); municipio de San Agustín Mezquititlán, $3 \mathrm{~km}$ al E del poblado El Rodeo, J. L. López G. 411 (IEB, MEXU, UAMIZ); municipio de Tenango de Doria, 20 miles N of Jacala, O. van Hyning 594 (US); municipio de Tlanchinol, $4 \mathrm{~km}$ al NE de Tlanchinol, sobre la carretera a Huejutla, J. Rzedowski 32687 (ENCB); municipio de Zacualtipán de Ángeles, alrededores de Zacualtipán, L. González Q. 342 (ENCB). México: municipio de Tlalmanalco, cañadas $3 \mathrm{~km}$ al S de San Rafael, J. Rzedowski 32714 (ENCB). Nuevo León: municipio de Santiago, Potrero Redondo, A. Contreras s. n. (MEXU); municipio de Galeana, Sierra Madre Oriental, San Francisco canyon, about 15 miles SW of pueblo Galeana, C. H. Muller \& M. T. Muller 324 (GH, MICH, P, TEX); municipio de General Zaragoza, Sierra Madre Oriental, Dulces Nombres, and just east of border into Tamaulipas, $24^{\circ}$ N, $99.5^{\circ}-100.5^{\circ}$ W, F. G. Meyer \& D. J. Rogers 2709 (BR); municipio de Santiago, mountain 20 miles south of Monterrey, J. D. Staub \& E. L. McWilliams s. n. (US(x2)); municipio de Monterrey, second canyon south of Monterrey toward Tampico, R. Ford Smith M30 (TEX); municipio de Aramberri, Kreuzung vor Aramberri, Schindhelm 2/93 (M(x2)); municipio de Aramberri, cerro El Viejo, G. B. Hinton et al. 25169 (IEB, TEX); municipio de Galeana, Agua Blanca a La Purísima, G. B. Hinton et al. 21831 (IEB, MICH, TEX); municipio de Galeana, Sierra Madre Oriental, cañón de San Francisco, C. H. Müller s. n. (MEXU(x3)); municipio de General Zaragoza, cerro El Viejo, G. B. Hinton et al. 22691 (TEX); municipio de Santiago, trail from La Trinidad to Potrero Redondo, C. H. Müller 2954 (GH, LL, MICH, UC). Querétaro: municipio de Landa de Matamoros, Llano Chiquito, S. Zamudio R. \& E. Carranza G. 10233 (IEB, UAMIZ); municipio de Landa de Matamoros, Joya del Hielo y alrededores, S. Zamudio R. \& E. Pérez C. 9918 (IEB); municipio de Peñamiller, cerro de San Nicolás Molinitos, S. Zamudio R. 5951 (IEB, UAMIZ(x2)); municipio de Peñamiller, ladera NE del cerro La Tembladera, $10.5 \mathrm{~km}$ al NE de Peña Blanca, $S$. Zamudio R. 9108 (IEB, UAMIZ); municipio de Pinal de Amoles, al SW de 4 Palos, E. Carranza G. 2976 (IEB(x2)). San Luis Potosí: municipio indefinido. Prov. de San 
Luis, Virlet D’Aoust 682 (P(x3)); municipio de Guadalcázar, aproximadamente 5 km de San José de las Flores por camino a Los Amoles a la mitad del camino entre ambos poblados, H. Hernández M., C. Gómez \& R. Bárcenas 3273 (MEXU, UAMIZ); municipio de Zaragoza, $3 \mathrm{~km}$ al NE de Calera, A. Rivera 29 (ENCB). Tamaulipas: municipio de Cruillas, Cerro Zamora, vicinity of El Milagro, H. H. Bartlett 11154 (GH(x2), MICH(x2)); municipio de Jaumave, Santa Rita Ranch, 40 miles south Victoria, $R$. Runyon 1033 (GH, US); municipio de Bustamante, ejido Ricardo García o La Presita, km 66 carretera Victoria - Tula, M. Martínez, M. Martínez \& L. Hernández S. 345 (MEXU); municipio de Hidalgo, near La Caballada, G. B. Hinton et al. 25188 (IEB, TEX); municipio de San Carlos, Sierra de San Carlos, ca. 5 m of San Carlos, N side of bufa El Diente, G. Nesom, M. Martínez \& J. Jiménez 6299 (TEX); municipio de San Carlos, Sierra de San Carlos en el cerro del Diente, 7 km (en línea recta) al W de San Carlos, M. Martínez \& J. Martínez 2042 (MEXU); 2046 (MEXU); municipio de San Carlos, cerro Bufa del Diente, S. Zamudio R. 11891 (UAMIZ). Tlaxcala: Sin localidad indicada, Schnée s. n. (P(x2).

Sill (Gardner) (2002) pointed out a possible relationship between the substrate and the flower color, suggesting that plants with green petals are saxicolous while those with violet petals are epiphytic. Neither the information from our database nor our personal observations confirm this possibility, since we have reports of plants of Tillandsia parryi growing as epiphytes (Ceja et al. 1298, 1300) or as saxicoles (Anderson s. n., Zamudio 9108, Carranza 2976, Martínez \& Martínez 2042, 2046).

\section{ACKNOWLEDGEMENTS}

We are very grateful to Bruce K. Holst for the critical revision of the manuscript, to Jacqueline Ceja and Aniceto Mendoza for their assistance with field work, and to Nancy Martínez Correa for the map included here. Also we thank the curators of the following herbaria for providing the facilities to consult specimens and data: BR, CICY, ENCB, GH, IEB, K, LL, M, MEXU, MICH, MO, P, PH, SEL, TEX, UAMIZ, UC, US and WU. The illustrations of the species were elaborated by Rolando Jiménez Machorro. The photograph was taken by Aniceto Mendoza. This work was partially supported by the Elizabeth Bascom Fellowship given by the Missouri Botanical Garden (2004) to the second author. 


\section{LITERATURE CITED}

Baker, J. G. 1887. A synopsis of Tillandsieae. J. Bot. 25: 277-281.

Ehlers, R. 1991. A new Tillandsia species: Tillandsia sueae. J. Bromeliad Soc. 41(5): 208213.

Gardner, C. S. 1982. A systematic study of Tillandsia subgenus Tillandsia. PhD. Thesis. University of Texas. Corpus Christi. 305 pp.

McVaugh, R. 1956. Edward Palmer, plant explorer of the American west. University of Oklahoma Press. Norman, Oklahoma. 430 pp.

Sill (Gardner), S. 2002. Tillandsia parryi and Tillandsia sueae, sister species of central Mexico. J. Bromeliad Soc. 52(4): 147-152. 